\title{
THE GERMAN
}

PREDICAMENT 



\section{THE GERMAN \\ P R E D I C A M E N T}

MEMORY AND POWER

IN THE NEW EUROPE

\section{ANDREI S. MARKOVITS and SIMON REICH}

CORNELL UNIVERSITY PRESS

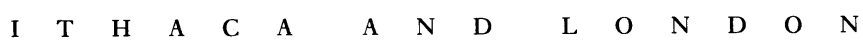




\section{Copyright (C) 1997 by Cornell University}

All rights reserved. Except for brief quotations in a review, this book, or parts thereof, must not be reproduced in any form without permission in writing from the publisher. For information, address Cornell University Press, Sage House, 512 East State Street, Ithaca, New York 14850.

First published 1997 by Cornell University Press

Library of Congress Cataloging-in-Publication Data

Markovits, Andrei S.

The German predicament : memory and power in the new Europe / by Andrei S. Markovits and Simon Reich.

p. $\mathrm{cm}$.

Includes index.

ISBN 0-8014-2802-5 (alk. paper).

1. Germany-Politics and government-1990 - 2. Germany-RelationsEurope. 3. Europe-Relations-Germany. 4. Political cultureGermany. I. Reich, Simon, 1959_ . II. Title.

DD290.29.M37 1997

$320.943-\mathrm{dc} 20$

Printed in the United States of America

This book is printed on Lyons Falls Turin Book, a paper that is totally chlorine-free and acid-free. 
To Irina and Linda

and

to the memory of our parents

with thanks 
"The past will not release us"

-Klaus Kinkel, German foreign minister, addressing the Bundestag, February 1996 